Utah State University

DigitalCommons@USU

1991

\title{
Mixed conifer and aspen regeneration in small clearcuts within a partially harvested Arizona mixed conifer forest
}

P.F. Ffolliott

G.J. Gottfried

Follow this and additional works at: https://digitalcommons.usu.edu/aspen_bib

Part of the Forest Sciences Commons

\section{Recommended Citation}

Ffolliott, P.F. and Gottfried, G.J., "Mixed conifer and aspen regeneration in small clearcuts within a partially harvested Arizona mixed conifer forest" (1991). Aspen Bibliography. Paper 2764.

https://digitalcommons.usu.edu/aspen_bib/2764

This Article is brought to you for free and open access by the Aspen Research at DigitalCommons@USU. It has been accepted for inclusion in Aspen Bibliography by an authorized administrator of DigitalCommons@USU. For more information, please contact

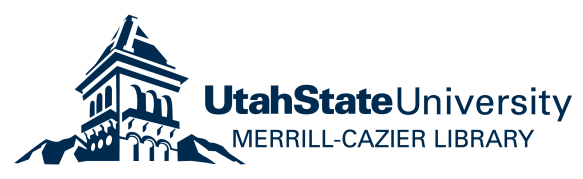




\title{
Mixed Conifer and Aspen Regeneration in Small Clearcuts Within a Partially Harvested Arizona Mixed Conifer Forest
}

\author{
Peter F. Ffolliott and Gerald J. Gottfried
}

\section{Introduction}

Southwestern mixed conifer forests are found on highelevation sites, generally above 8,000 feet, throughout Arizona, New Mexico, and southwestern Colorado. The forests are an important source of wood products for the Southwest and also provide a wide range of commercial and noncommercial resources. Natural regeneration appears to be satisfactory in most undisturbed stands. These contain adequate numbers and stocking of advance regeneration to replace trees lost by natural mortality or by moderate harvesting. However, natural regeneration is poor when large openings are created by harvesting or natural disturbances. Jones (1967) found little natural or successful artificial regeneration in the clearcut blocks on Burro Creek, in eastern Arizona, 7 years after harvesting. He also found that most natural regeneration in a 10-acre clearcut occurred within 66 feet of the timber margin, and recommended that openings be no wider than 198 feet to enhance natural regeneration. Ronco et al. (1984) supported this observation by reporting that most conifer seed falls within 198 feet of the windward timber edge. Many large mixed conifer openings only regenerate rapidly because of abundant aspen suckering, although conifer numbers and stocking will gradually increase (Gottfried 1983).

The harvesting of mixed conifer forests to create small patch clearcut openings of 1 to 2 acres has been advocated as a method of increasing water yields from these relatively moist areas (Hibbert 1979, Rich and Thompson 1974), as well as enhancing other resource values. Such a prescription is consistent with the silvicultural recommendations of Alexander (1974) and Jones (1974) for southwestern mixed conifer forests. Under this option, a portion of the watershed would be patch clearcut periodically throughout the stand rotation. Once harvested, the openings would regenerate naturally, and eventually contain sufficient timber to be harvested again at the end of a 120-year rotation. A basic hypothesis associated with such a prescription is that natural regeneration in these small clearings would be adequate to sustain forest productivity. In addition to greater availability of seed from the surrounding stand, small openings should have a more moderate microclimate, as well as better moisture conditions than larger openings because of increased snow accumulations and reduced evapotranspiration. It is assumed that these conditions should benefit the major species, including the more shade-intolerant pines (Pinus spp.) and aspen (Populus tremuloides). The hypothesis concerning regeneration success in small clearcuts has never been evaluated fully in the Southwest.
A prescription that included creating small, dispersed openings by patch clearcutting and group-selection methods, in conjunction with single-tree selection in the adjacent stand, is currently being evaluated at Thomas Creek, in the White Mountains of east-central Arizona. A resource allocation evaluation (Brown 1976) indicated that this prescription would benefit the greatest mix of mixed conifer resources, such as water yields, herbage production, many wildlife populations, and tree and stand growth. Successful tree regeneration was an important factor; the lack of adequate natural regeneration in the clearings would limit the usefulness of the prescription for multiresource management. The objective of the present study, which is a part of the multiresource study at Thomas Creek, was to determine if the small mixed conifer clearcuts have regenerated satisfactorily in the 11 years since harvesting. The specific objective was to evaluate the amount, composition, and stocking of natural mixed conifer and aspen regeneration in small clearcuts, and to compare it to regeneration in the surrounding partially harvested forest. The results from this study should also be applicable to group-selection openings of similar sizes, although this was not specifically evaluated.

\section{Study Area}

The study was conducted on the South Fork of Thomas Creek, a 562-acre watershed in the ApacheSitgreaves National Forests, about 15 miles south of Alpine, Ariz. Elevations on South Fork range from 8,350 to 9,150 feet. Soils in the study area, which are primarily sandy loams derived from basaltic parent materials, have been classified as Mollic Eutroboralfs loamyskeletal mixed (Sexton 1976). Average annual precipitation is over 30 inches (fig. 1), approximately $56 \%$ of which occurs from October through May, mostly as snow. July and August receive the most monthly precipitation, with means of 4.5 and 4.4 inches, respectively. Precipitation during the first 8 years of the posttreatment period was significantly higher than the average for the previous 14-year pretreatment period (fig. 1).

The South Fork of Thomas Creek originally supported an old-growth, uneven-aged, mixed conifer forest consisting of eight main tree species: Engelmann spruce (Picea engelmannii), blue spruce ( $P$. pungens), Douglasfir (Pseudotsuga menziesii var. glauca), white fir (Abies concolor), corkbark fir (A. lasiocarpa var. arizonica), ponderosa pine (Pinus ponderosa), southwestern white pine (P. strobiformis), and quaking aspen. Preharvest forest conditions for the South Fork sale area are given 


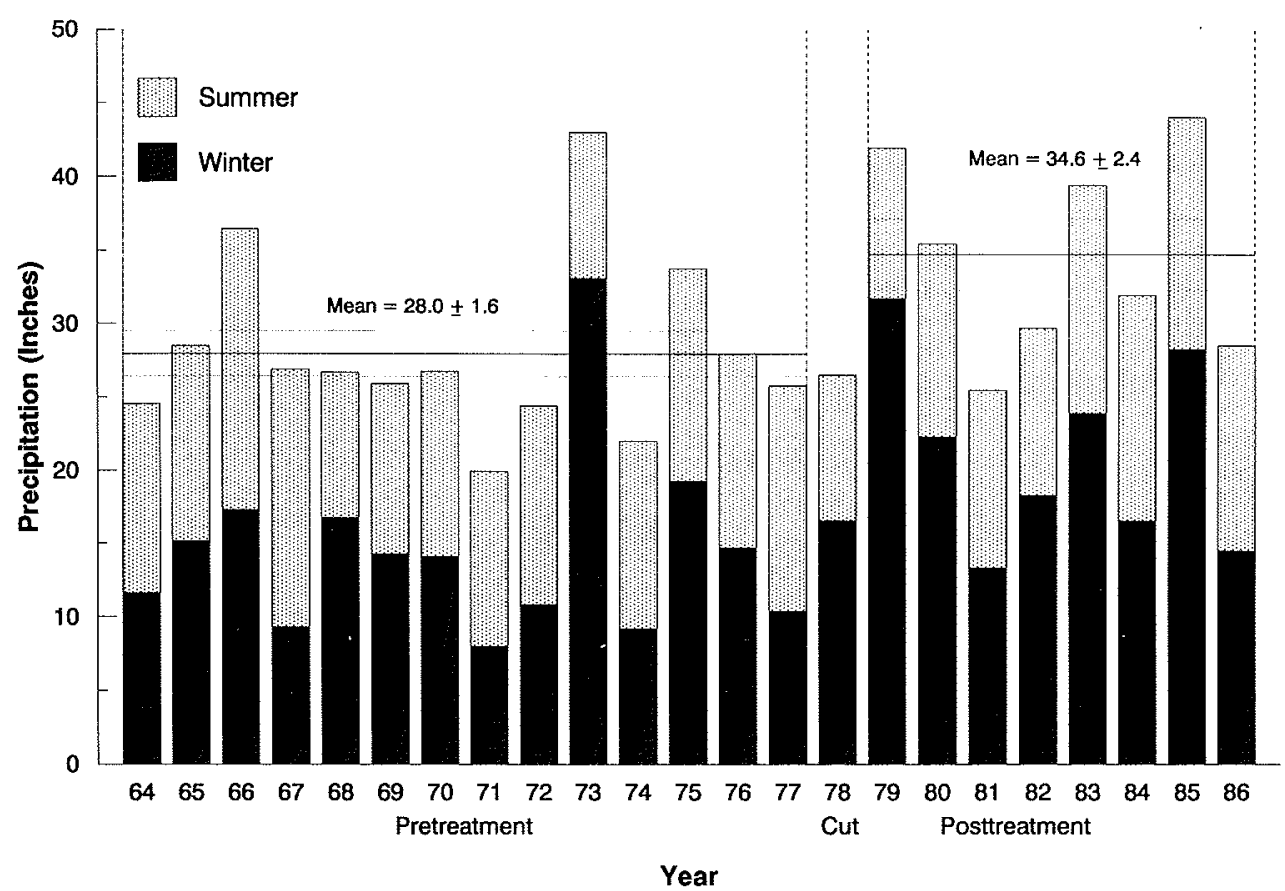

Figure 1.-Annual precipitation at the Thomas Creek recording precipitation gage can be divided into winter and summer seasons.

Table 1.-Forest changes in the Thomas Creek South Fork harvesting unit for trees $\geq 1$ inch diameter breast high (on a per acre basis). The 1979 values reflect growth of survivor trees and the reductions associated with harvesting and natural mortality.

\begin{tabular}{|c|c|c|c|c|c|c|}
\hline \multirow[b]{2}{*}{ Species } & \multicolumn{3}{|c|}{ Pretreatment (1974) } & \multicolumn{3}{|c|}{ Posttreatment (1979) } \\
\hline & Trees & $\begin{array}{l}\text { Basal } \\
\text { area }\end{array}$ & $\begin{array}{l}\text { Total } \\
\text { tree } \\
\text { volume }\end{array}$ & Trees & $\begin{array}{l}\text { Basal } \\
\text { area }\end{array}$ & $\begin{array}{c}\text { Total } \\
\text { tree } \\
\text { volume }\end{array}$ \\
\hline & no. & $f t^{2}$ & $B M^{\dagger}$ & no. & $f t^{2}$ & $B M^{1}$ \\
\hline $\begin{array}{l}\text { Engelmann spruce } \\
\text { Blue spruce } \\
\text { Douglas-fir } \\
\text { White fir } \\
\text { Corkbark fir } \\
\text { Ponderosa pine } \\
\text { Southwestern white pine } \\
\text { Quaking aspen }\end{array}$ & $\begin{array}{r}19.04 \\
7.90 \\
122.85 \\
51.75 \\
7.55 \\
40.56 \\
64.49 \\
47.46\end{array}$ & $\begin{array}{r}12.50 \\
6.91 \\
66.22 \\
40.16 \\
3.72 \\
30.59 \\
19.68 \\
19.68\end{array}$ & $\begin{array}{r}1,631 \\
1,020 \\
7,876 \\
6,375 \\
427 \\
5,931 \\
2,260 \\
1,752\end{array}$ & $\begin{array}{r}15.26 \\
6.22 \\
94.42 \\
27.66 \\
7.01 \\
34.23 \\
47.08 \\
40.93\end{array}$ & $\begin{array}{r}9.58 \\
4.52 \\
42.82 \\
23.40 \\
3.19 \\
16.75 \\
13.83 \\
17.55\end{array}$ & $\begin{array}{r}1,188 \\
584 \\
4,536 \\
3,387 \\
307 \\
2,934 \\
1,441 \\
1,509\end{array}$ \\
\hline $\begin{array}{l}\text { Total } \\
\text { Percent change }\end{array}$ & $\overline{361.60}$ & $\overline{199.47}$ & $\overline{27,272}$ & $\begin{array}{r}272.81 \\
25\end{array}$ & $\begin{array}{r}131.64 \\
34\end{array}$ & $\begin{array}{r}15,886 \\
42\end{array}$ \\
\hline
\end{tabular}

${ }^{1} B M=$ Board feet.

in table 1. Douglas-fir was the most common species, while ponderosa pine was the most commercially valuable species. The stand consisted of a mosaic of groups and patches of various sizes and species compositions. Although Fitzhugh et al. (1987) classified the Thomas Creek stand as belonging to the Picea engelmannii/ Senecio cardamine habitat type (PIEN/SECA), Abies concolor phase, the study sites contain some characteristics of the Abies concolor/Muhlenbergia virescens habitat type (Moir 1990, pers. comm.). An intensive survey of advance regeneration prior to harvesting indicated 1,928 trees per acre between 3 inches and 0.9 feet in height
(Gottfried 1987). White and corkbark fir were the most common species observed.

The multiresource prescription was prepared for the 422 acres in the upper part of the South Fork watershed; the lower areas were withdrawn from the timber sale because of locally steep slopes. The prescription called for group selection and single-tree selection on 233 acres, patch clearcutting and single-tree selection on 159 acres, and single-tree selection on 28 acres adjacent to the stream channel. Two acres of meadow were left undisturbed. Harvesting operations were primarily conducted in 1978, removing approximately 3.4 million 
board feet of volume (Scribner Decimal C), after deducting for defect, and reducing stand basal area in the sale area by $34 \%$ (table 1). The harvest created 63 dispersed patch clearcut and group-selection openings throughout the entire sale area. Openings covered $13 \%$ of the watershed.

\section{Methods}

Prior to harvesting in 1978, established mixed conifer seedlings and aspen suckers were measured in nine forested areas that had been marked for patch clearcutting. Regeneration in each area was measured along two transects that intersected at right angles. Circular 1-milacre plots were established at 50-foot intervals along the transects, which extended approximately 150 feet into the forest adjacent to the marked opening. Trees tallied in the milacre plots were classified as seedlings or suckers if they were less than 1 foot in height, or as advance regeneration if they were between 1 and 4.5 feet in height. A plot was considered stocked with a species if at least one healthy tree was present. The initial survey did not include a complete tree count for all species. Number of stems and percent stocking were recorded by tree species. These data provided an indication of pretreatment conditions on the study area.

Following the harvest, 9 of the 63 harvested clearings were selected for intensive study. Permanently located transects and milacre sampling plots were established in the clearings and in the adjacent partially harvested forested areas. The characteristics of the nine sites, including the surrounding stands, are shown in table 2 . The overstory basal areas were measured in 1989 by point sampling procedures using a 25 basal area factor wedge. The openings were in areas that generally were level, with some slope to the north. Slash disposal activities had been conducted in all sites. Five of the nine sites had been sampled prior to harvesting. The current analysis is based on measurements of regeneration in the nine sites from 1982 through 1989. These areas also have been used to study snow accumulation patterns (Plasencia 1988) and the production and utilization of herbaceous plants (Ffolliott and Gottfried 1989).
Seedling measurements, including number of stems, species, and percent stocking, were made in 1982, 1983, 1986, and 1989, representing 4, 5, 8, and 11 years following treatment. Because it often was difficult to distinguish between small seedlings of the same genus, Engelmann spruce and blue spruce were combined into one class, as were white fir and corkbark fir. The combined groups retain the name of the more common species; blue spruce and corkbark fir were not commonly found in the sample. It is recognized that the two species within a class have different regeneration requirements. The original survey in 1982 only considered trees less than 1 foot tall to avoid trees that had become established prior to harvesting. Subsequent surveys removed this restriction as long as the tree appeared to date from the logging period. Individual trees were not identified, so tallies included trees that had been present since 1978 as well as younger trees. Some trees tallied in one survey may not have survived until a subsequent visit. Seedling heights were only measured in 1989. In line with the Forest Service's requirements for high-site mixed conifer stands (Bassett 1990, pers. comm.), we considered an opening to be satisfactorily regenerated if it contained at least 325 trees per acre.

Comparisons between regeneration density and stocking in the nine openings and under the surrounding forested areas, for each measurement date, were evaluated by paired t-tests (values are given as means and standard errors). Changes over time, as well as time $x$ type (opening or forest) and time $\times$ site interactions, were analyzed by repeated measures procedures. Height data for all regeneration were pooled for analysis because of the varying sample sizes among plots; for example, not all species were present on all plots or within each cover group. Density data also were grouped by five height categories (0-3 inches, 4-6 inches, 7-12 inches, 13-24 inches, and greater than 25 inches) for comparison between forest and clearcuts by paired t-test analysis. In addition, an attempt was made to relate the density of reproduction in the open to various opening, forest, and herbage production-utilization characteristics using regression techniques. A similar attempt was made to relate regeneration in the forest to residual overstory density. Data were not transformed for these analyses. State-

Table 2.-Characteristics of the nine clearings and adjacent partially harvested stands.

\begin{tabular}{|c|c|c|c|c|}
\hline $\begin{array}{l}\text { Opening } \\
\text { number }\end{array}$ & $\begin{array}{c}\text { Area } \\
\text { (acres) }\end{array}$ & $\begin{array}{c}\text { Basal area } \\
\left(\mathrm{ft}^{2} / \mathrm{acre}\right) \\
\overline{\mathrm{X}} \pm \mathrm{SE}\end{array}$ & $\begin{array}{c}\text { Mean tree } \\
\text { height (ft) } \\
\bar{X}_{ \pm} \text {SE }\end{array}$ & $\begin{array}{l}\text { Most common species } \\
\text { (percent by basal area per acre) }\end{array}$ \\
\hline 1 & 1.2 & $146 \pm 29$ & $64 \pm 7$ & White fir $(26 \%)$, ponderosa pine $(23 \%)$ \\
\hline 2 & 0.8 & $156 \pm 20$ & $94 \pm 6$ & Douglas-fir $(40 \%)$, white fir $(15 \%)$ \\
\hline 3 & 1.1 & $148+22$ & $90 \pm 5$ & Douglas-fir $(44 \%)$, white fir $(13 \%)$ \\
\hline 4 & 1.1 & $158 \pm 22$ & $59 \pm 6$ & Douglas-fir $(54 \%)$, ponderosa pine $(22 \%)$ \\
\hline 5 & 0.8 & $158 \pm 21$ & $62 \pm 7$ & Douglas-fir $(59 \%)$, aspen $(21 \%)$ \\
\hline 6 & 0.3 & $169 \pm 26$ & $72 \pm 7$ & Douglas-fir $(51 \%)$, Engelmann spruce $(12 \%)$ \\
\hline 7 & 1.1 & $123+23$ & $57 \pm 4$ & Engelmann spruce $(32 \%)$, Douglas-fir (27\%) \\
\hline 8 & 1.0 & $208 \pm 31$ & $56 \pm 5$ & Aspen $(34 \%)$, Douglas-fir $(26 \%)$ \\
\hline 9 & 1.6 & $191 \pm 22$ & $85 \pm 6$ & Douglas-fir $(45 \%)$, white fir $(45 \%)$ \\
\hline \multicolumn{5}{|r|}{ 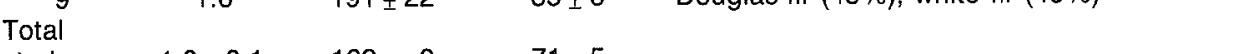 } \\
\hline study area & $1.0 \pm 0.1$ & $162 \pm 8$ & $71 \pm 5$ & \\
\hline
\end{tabular}


ments referring to increases or decreases, and greater or lesser, indicate that the differences were statistically significant at the $5 \%$ level.

\section{Results}

\section{Density and Composition}

The 1978 preharvest survey measured approximately 1,746 seedlings and suckers per acre less than 1 foot in height (table 3). Douglas-fir and white fir accounted for $67 \%$ of these trees, while aspen accounted for $25 \%$ (fig. 2). The numbers of Douglas-fir and white fir were statistically similar. Although the study was concerned primarily with seedlings, larger advance regeneration also was tallied during this survey. Douglas-fir and white fir predominated in this size class too, contributing $52 \%$ of the density of $651 \pm 116$ trees per acre. Aspen made up $34 \%$ of the advance regeneration.

In 1982, the year of the first postharvest survey, all of the nine openings and all of the adjacent partially harvested areas were satisfactorily regenerated, containing at least 325 seedlings or suckers per acre. The difference between the mean for openings and for the forested areas was not statistically significant (table 3). Aspen made up $12 \%$ of the trees in the forest and $8 \%$ of the trees in the clearings (fig. 2). This species was found in most forested areas but was concentrated in three openings. The aspen comparison, as well as those for all conifers except white fir, did not indicate statistically significant differences between the two cover conditions. There were more white fir seedlings in the forest than in the openings (table 3). White fir and Douglas-fir were the most common species, comprising $75 \%$ of the seedlings in the forest and $80 \%$ in the clearings (fig. 2). There were more white fir than Douglas-fir seedlings in the forest but their densities were similar in the clearings. This relationship between white fir and Douglas-fir was true for all of the surveys except 1986.

In 1983, a year later, regeneration densities declined sharply in both forested and open sites (table 3); differences between 1982 and 1983 were highly significant. The 1983 inventory indicated that only six of the openings contained satisfactory numbers of seedlings and suckers. One opening, which had over 1,000 trees per acre in 1982, contained no regeneration in 1983. All of the forested areas contained at least 325 seedlings or suckers per acre. The average clearcut opening still contained 1,082 trees per acre, while the forest averaged 2,272 trees per acre; these values were not statistically different. Conifer and aspen numbers were also similar between the two cover types; only white fir showed a significant difference between cleared and forest sites (table 3). All nine sites responded the same with respect to total tree numbers; however, in two sites increases were noted in the number of conifers in the forest, while density decreased in the open. Aspen regeneration densities between 1982 and 1983 did not follow the general trend; they increased in the openings (table 3), making up about $46 \%$ of the average density (fig. 2), and declined slightly in the forest, making up $14 \%$ of the regeneration. However, most aspen regeneration was again concentrated in three clearings; this is reflected in the high standard error. Aspen regeneration was found in both the largest and smallest clearings. White

Table 3.-Total, total conifer, and individual species regeneration density per acre (mean standard error) by survey date. ${ }^{1}$

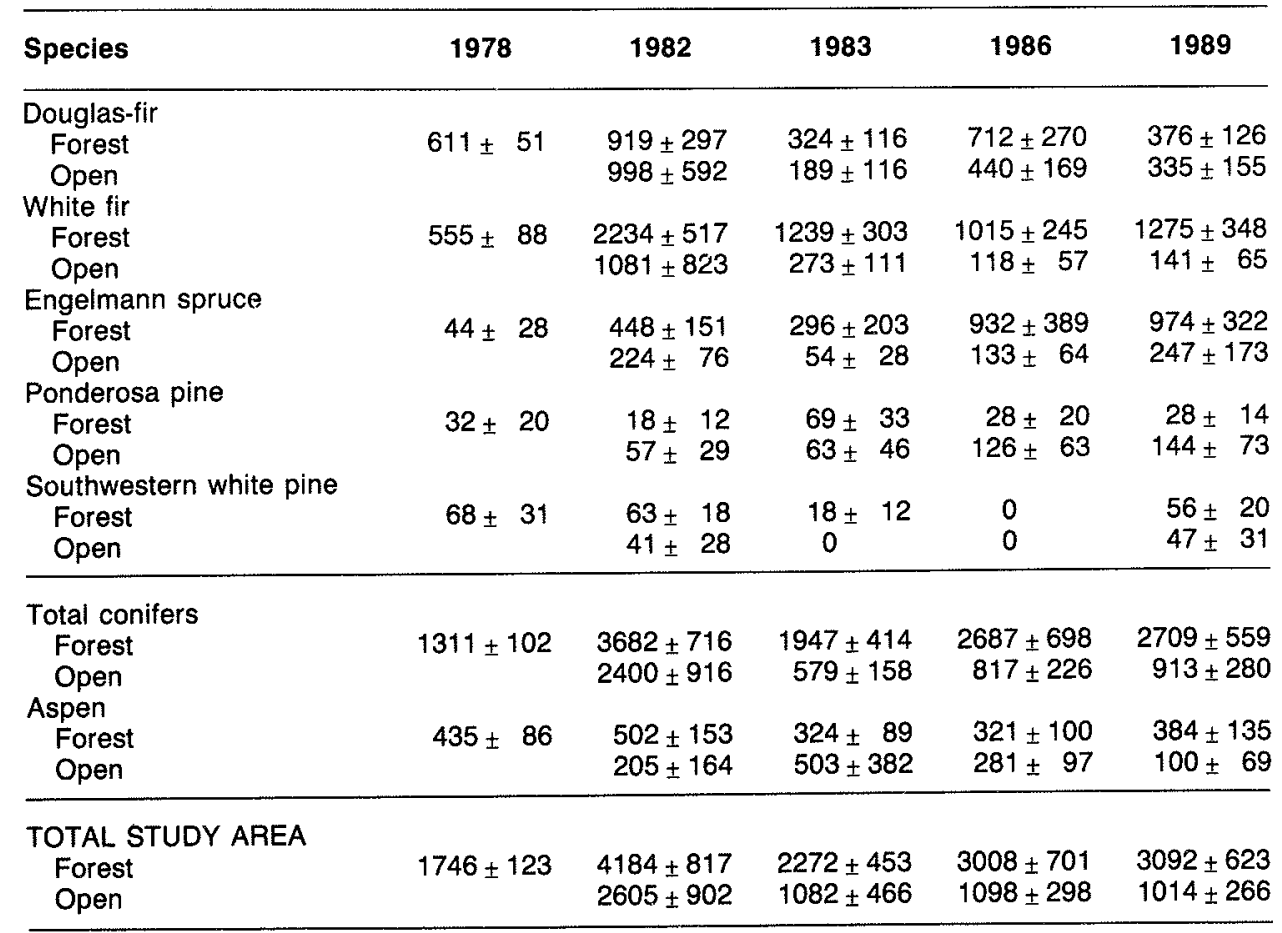

${ }^{1}$ Columns may not add up exactly because of rounding to integer values. 
fir and Douglas-fir contributed $69 \%$ of the seedlings in the forested areas and $43 \%$ in the open (fig. 2); the proportion of white fir in the openings declined from $42 \%$ to $25 \%$.

By 1986, seedling density appeared to be recovering (table 3), but the new levels still were below those of 1982; they were statistically similar to those of 1983. Eight of the openings and all of the forested areas contained satisfactory numbers of seedlings. However, the difference between the two cover conditions had become significant, with openings containing 1,098 trees per acre and forested areas containing 3,008 trees per acre. Total conifer densities also were significantly different between cover types, but only white fir densities indicated a species difference. This species declined in the openings between 1983 and 1986 (table 3). Aspen made up $26 \%$ of the trees in the openings and $11 \%$ of those in the forest (fig. 2). The percentage of Douglas-fir and white fir was $57 \%$ in the forest and $51 \%$ in the open. In 1986, white fir and Douglas-fir numbers were equivalent in both areas (table 3).

Total regeneration density remained constant between 1986 and 1989 (table 3) and continued to be below the

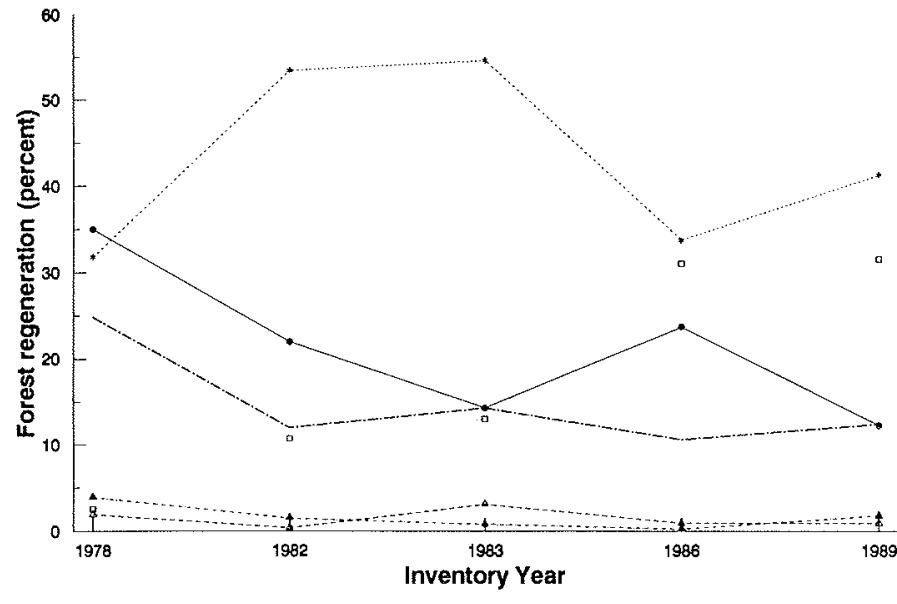

Douglas-Fir White Fir Engelmann Spruce Ponderosa Pine White Pine Aspen

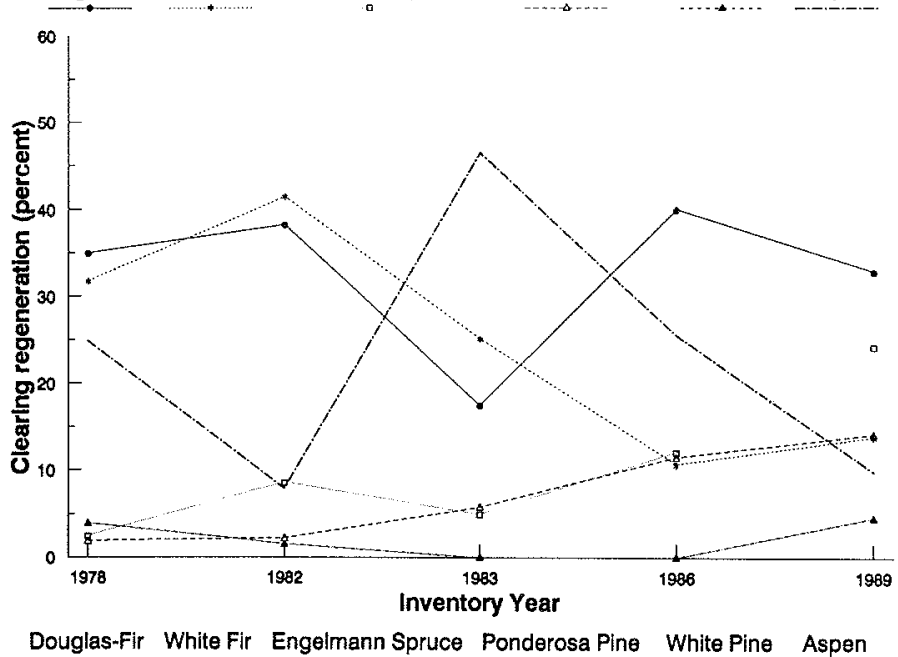

Douglas-Fir White Fir Engelmann Spruce Ponderosa Pine White Pine Aspen

Figure 2.-Regeneration species composition, as a percent of total seedling density per acre, varied over the study, particularly for white fir, aspen, and spruce. Fluctuations appear greater in the open (bottom) than in the forest (top).
1982 levels. In fact, respective densities had remained similar since 1983. Eight openings and all forested areas contained satisfactory seedling and sucker densities. The clearing that contained no regeneration in $1983 \mathrm{re}$ mained unchanged. The difference between density in the open and in the forest was significant. Differences were also found between populations of conifers; however, white fir was still the only species to show differences (table 3 ). The aspen component made up $10 \%$ of the trees in the open and $12 \%$ of those in the forest (fig. 2). Douglas-fir and white fir accounted for $53 \%$ of the forest seedlings and $47 \%$ of the clearing seedlings. The proportion of spruce increased from $11 \%$ to $32 \%$ in the forest and from $9 \%$ to $24 \%$ in the clearings between 1982 and 1989 (fig. 2). Spruce was only $2 \%$ of the pretreatment regeneration density. Spruce densities in the study sites have increased significantly since the 1982-1983 decline (table 3). Regeneration densities were almost three times greater on the south sides of the openings $(1,685$ trees per acre $)$ than on the north sides, but this was not confirmed statistically because of the high variability among sites.

\section{Percent Stocking}

The pretreatment inventory indicated that $88 \% \pm 4 \%$ of the plots were stocked with at least one seedling or aspen sucker. Stocking evaluations following harvesting showed no statistical differences between forest and open areas over the study period (fig. 3). Stocking dropped significantly between 1982 and 1983 and remained constant afterwards. In 1989, stocking ranged from 0 to $100 \%$ in the clearcut openings, with a mean of $45 \% \pm 9 \%$; it ranged from $20 \%$ to $92 \%$ in the forest, with a mean of $61 \% \pm 8 \%$. Stocking in the openings would have averaged $51 \% \pm 8 \%$ if the nonstocked area were not included. Most of the trees in the clearings were adjacent to the treeline; only two areas had trees in the center milacre plot. Average stocking was similar between the north and south sides of the openings. Although the smallest opening was $100 \%$ stocked, there did not appear to be a relationship between opening size and stocking in the study.

\section{Seedling Heights in 1989}

Average seedling and sucker heights for all species were similar between the two cover groups; the average height was 8.3 inches in the forest and 8.0 inches in the open. Average heights were similar within eight of the forest-opening pairs. On one site, the average height was greater in the forest. Average numbers of seedling per acre compared by height class and cover were as follows:

\begin{tabular}{ccr}
$\begin{array}{c}\text { Height class } \\
\text { (inches) }\end{array}$ & \multicolumn{2}{c}{$\begin{array}{c}\text { Regeneration density }(\overline{\mathbf{X}} \pm \\
\text { Forest }\end{array}$} \\
$0-3$ & $804 \pm 267$ & $212 \pm 129$ \\
$0-3$ & $853 \pm 214$ & $319 \pm 110$ \\
$4-6$ & $879 \pm 247$ & $242 \pm 76$ \\
$7-12$ & $419 \pm 128$ & $218 \pm 101$ \\
$13-24$ & $138 \pm 52$ & $22 \pm 22$ \\
$\geq 25$ & &
\end{tabular}


Differences between cover categories for the second and third height classes were significant. Differences were also indicated when the first three classes were combined and compared but not when the last two were compared. The first three classes represented $82 \%$ of the seedlings in the partially harvested stand and $76 \%$ of those in the open.

\section{Regression Analyses}

The attempts to develop significant multiple regressions between seedling density in the open and various stand, herbage, and physical parameters, were unsuccessful. The best regression, for the 1983 data, only explained $49 \%$ of the variation, but this was not statistically significant. The attempt to define regeneration density by overstory basal area using linear regression methods was also unsuccessful.

\section{Discussion}

Patch clearcutting, in association with other silvicultural methods, has been advocated as a method of increasing water yields, enhancing range and wildlife

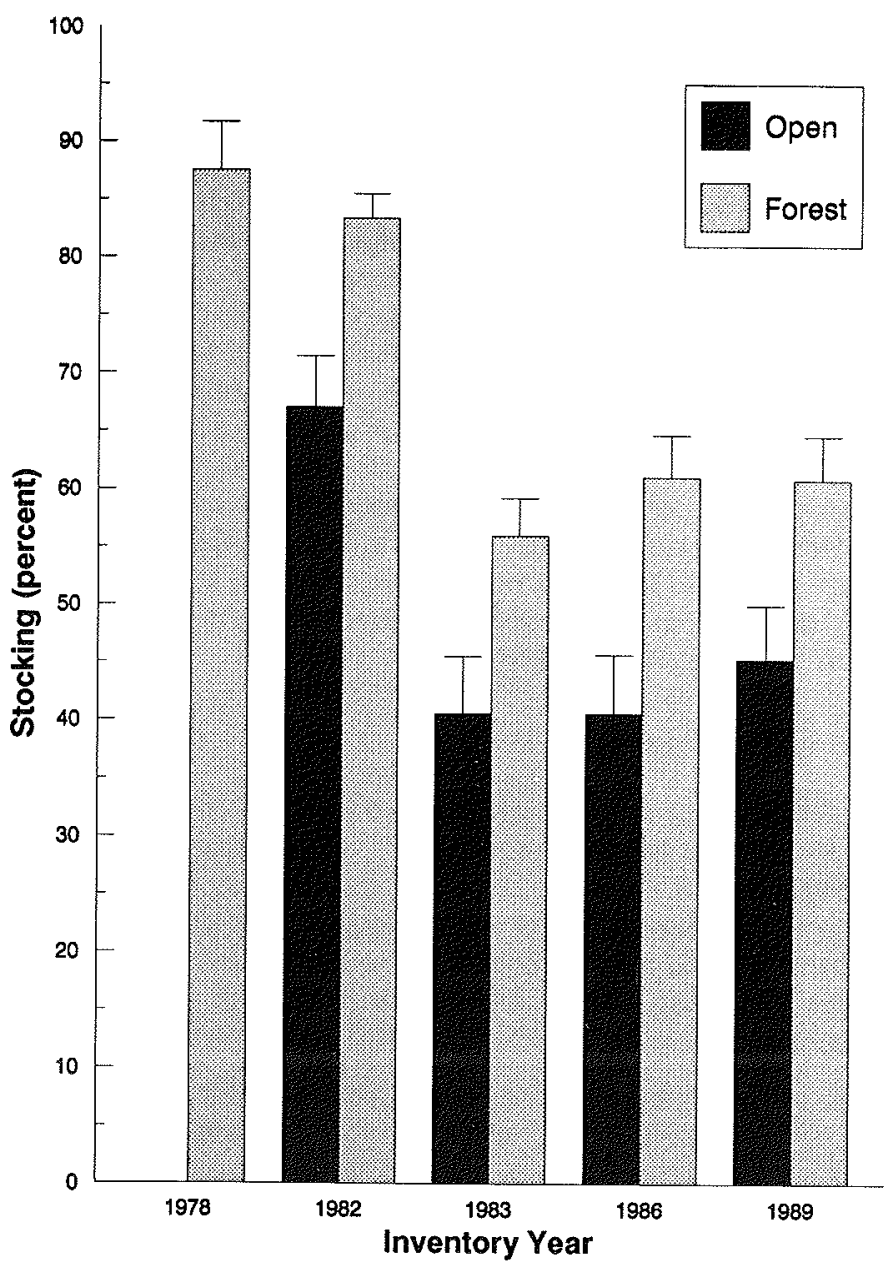

Figure 3.-Average percent stocking was similar for both the openings $(O)$ and forested areas $(F)$ over the study. Stocking appears relatively constant from 1983 to 1986 . values, and regenerating the southwestern mixed conifer forests. The prescription based on this hypothesis currently being evaluated at Thomas Creek is compatible with the Forest Service integrated resource management (IRM) goals for land management, which are based on the philosophy that all resources are interrelated (USDA Forest Service 1988). Gottfried (1989) found that the treatment resulted in an average water yield increase of $45 \%$ ( 1.7 inches), and that diameter growth of most species in the residual stand also increased relative to an adjacent uncut stand. Similarly, Ffolliott and Gottfried (1989) found that openings produced more herbage than adjacent partially harvested areas. However, these multiresource benefits would have been compromised if the treatment did not result in adequate tree regeneration to sustain forest productivity.

This study showed that in 1989,11 years after the timber harvest, eight of the nine monitored clearings had regenerated satisfactorily, with an average density of 1,014 new seedlings and suckers per acre. Although this was significantly less than the density under the adjacent partially harvested forest, it was sufficient to regenerate the clearcut openings. Each of the eight stocked openings contained at least 325 trees per acre, the level considered to indicate satisfactory density. Regeneration densities were not influenced by differences in site characteristics (table 2). Regeneration densities under the forest, which had been harvested according to the single-tree selection method, were also greater than that considered satisfactory and greater than that measured before treatment.

An average of $45 \%$ of the inventory milacre plots in the clearings were stocked; this was similar to conditions in the adjacent forest where $61 \%$ were stocked. Most seedlings in the openings were growing next to the treeline. The stocking results were less satisfactory since it would be best if the regeneration were distributed over at least $75 \%$ of the area. However, the center areas should become stocked in the future as the surrounding established seedlings grow and further modify the microclimate in the open. Although regeneration in the representative small clearcut openings cannot be considered a complete success, the results are satisfactory.

Seedling and sucker densities fluctuated throughout the study period. The initial survey, prior to harvesting, measured approximately 1,746 stems per acre (table 3 ); this value is similar to the 1,928 seedlings per acre measured in the same area by Gottfried (1987). In 1982 , seedling densities were at their highest levels on all areas. High survival could have been related to the precipitation that occurred in Arizona during the preceding few years (fig. 1). Seed production was not measured, but a good seed crop combined with favorable moisture conditions could account for initial germination success. Stocking averaged $83 \%$ under the forest canopy and $67 \%$ in the open (fig. 3). It is uncertain why a year later, seedling densities generally declined significantly in both forest and open zones. However, Ffolliott and Gottfried (1989) found similar fluctuations in herbage production within the same areas. Although 1983 had higher than normal annual precipitation (fig. 1), the 
decline in herbage production may be related to the relatively low precipitation in May, June, and August of 1983, and to cooler temperatures in May and June of that year (Ffolliott and Gottfried 1989). Moisture would be more critical to young seedlings, but temperature would be important for germination of seed, especially for true firs and white pine, which germinate in the spring (Ronco et al. 1984). Seedling numbers have remained relatively constant since 1983 (table 3), although forested areas have shown consistent increases. The differences between the two cover classifications were significant in 1986 and 1989.

Although each of the species has its own requirements for germination and establishment (Ronco et al. 1984), the conifer species generally have followed the same pattern of fluctuations as found for total regeneration densities. Individual species population densities have remained similar within the partially harvested stand and the openings throughout the study (table 3). Only white fir numbers were different for the two cover categories for each of the four surveys. Jones $(1971,1972)$ found that true firs and spruce can be at more of a disadvantage during drought periods than pines because of their shallow and slow-growing root systems. More drought-hardy species have rapid-growing root systems, which can tap moisture from deeper soil layers where evaporation losses are less. Young seedlings in clearings are subject to greater environmental stresses than seedlings protected by a forest canopy. Solar radiation parameters and temperatures are higher in the open during the day (Lee 1978), although small openings have more moderate microclimates than larger clearings. The apparent higher regeneration densities observed on the shaded south sides of openings are an indication of more moderate site conditions. Greater herbaceous cover could increase tree mortality and reduce germination because of moisture competition, especially during a drought period (Embry 1971). The impacts of slash disposal on regeneration within clearings should also be evaluated. Slash moderates the microclimate near the soil surface and has been shown to benefit certain species, such as spruce (Ronco et al. 1984).

Ideally, clearings can be created that will favor one species or group of species over other alternatives. It is possible that a test of a wider range of opening sizes would have indicated potential conditions for species manipulations. It was expected, for example, that openings might provide sufficient light to encourage regeneration of shade-intolerant ponderosa pine. Overstory ponderosa pine occurred in all of the forested areas adjacent to the openings. The four surveys did not indicate any differences between densities in the forest and the open for this pine (table 3); however, the relative importance of ponderosa pine within the openings did appear to show an increase over time (fig. 2). Larger openings could have possibly resulted in increased ponderosa pine regeneration densities. Engelmann spruce, a shade-tolerant species, however, increased over the study period (table 2 , fig. 2 ). The species has a reproductive advantage since it has consistent annual seed production (Ronco et al. 1984). By 1989, it was the second most common seedling species under the partially harvested stand and in the clearings. Spruce was concentrated in four openings. The success of spruce in these clearings may be an indication that the size, shape, or orientation of the openings was beneficial for this species but did not allow sufficient sunlight penetration to favor shade-intolerant species. The increase in this species may validate the habitat type classification of Fitzhugh et al. (1987) for some of the sites.

Aspen increased in the clearcuts between 1982 and 1983 (table 3). Aspen is a clonal species; suckers in the openings were probably connected to older trees in the surrounding stand, and could obtain moisture and nutrients from them. Conifer seedlings would not have this advantage. Except in 1983, aspen was not as large a component of the regeneration as would be expected. Gottfried (1983) indicated that intensive aspen suckering was the main reason that the heavily harvested areas on the adjacent Willow Creek watershed were regenerated within a reasonable time. However, the Willow Creek openings were fairly large. It is possible that insufficient light was reaching the soil in the small clearings to stimulate heavy suckering and to sustain aspen reproduction. It also is possible that apical dominance of adjacent large aspen may have suppressed sprouting activity. Heavier utilization of the openings by wildlife and livestock, as reported by Ffolliott and Gottfried (1989), may be another reason for low aspen regeneration. Larger clearings should be more beneficial for aspen, but the best size has not been determined.

The Thomas Creek sample included a mix of ages, as well as species. Some trees were 1 year old and others were over 11 years old. Even though there were differences in tree densities, the majority of the trees within the forest and clearings were 12 inches or less in height; many factors affect height growth but most of the trees within a height class probably germinated during the same period. The similarity in the $0-3$ inch class indicates that recruitment is continuing in the stand, although relative efficiency cannot be determined without seed crop information. Trees in the 13-24 inch class represent $22 \%$ of the trees in the openings and $14 \%$ of those under the canopy. Although these differences were not statistically significant, it is generally expected that trees of the same age would grow faster in the open than under the shade of the overstory. Jones (1971) determined that even shade-tolerant Engelmann spruce grew better in a large opening than in either an intermediate or small opening. Douglas-fir benefited more from its location in a large opening than did spruce; it grew about 20 inches in 6 years, while spruce grew slightly less than 15 inches. A larger sample of regeneration or even identifying trees throughout the study period would have facilitated a more rigorous test of height growth in the two environments.

Regeneration was better in the small clearings than in the large clearcuts examined by Jones (1967), or the heavily harvested diameter-limit area examined by Gottfried (1983). Better reproduction is expected for a number of reasons. Small openings generally receive sufficient seed because most of the regeneration sites are within 198 feet 
of the forest edge. Even a circular 1.6-acre opening, which would be larger than 198 feet in diameter, should receive seed from both upwind and downwind edges. Jones (1967) found an average of 63,000 filled, mixed conifer seeds per acre in a 10 -acre clearcut over a 3 -year period. Spruce seed was most common, followed by Douglas-fir; true firs and ponderosa pine seed made up $10 \%$ of the average in the clearcut. However, over 500,000 seeds per acre were found along the upslope, windward margin of the opening during a later bumper seed crop year (fig. 4).

Small openings have more moderate microclimates than larger openings. The extent to which an opening affects the microclimate depends upon its size in relation to the height of the surrounding overstory trees (Lee 1978); factors such as slope, aspect, and the shape are also important. There is more shade in small clearings from the surrounding overstory, which tends to reduce soil and air temperatures; and there usually is less wind movement, which impacts air mixing and the pressure gradients that affect evapotranspiration. Moderate nighttime temperatures, caused by back radiation from the forest, have been found to reduce frost damage to young

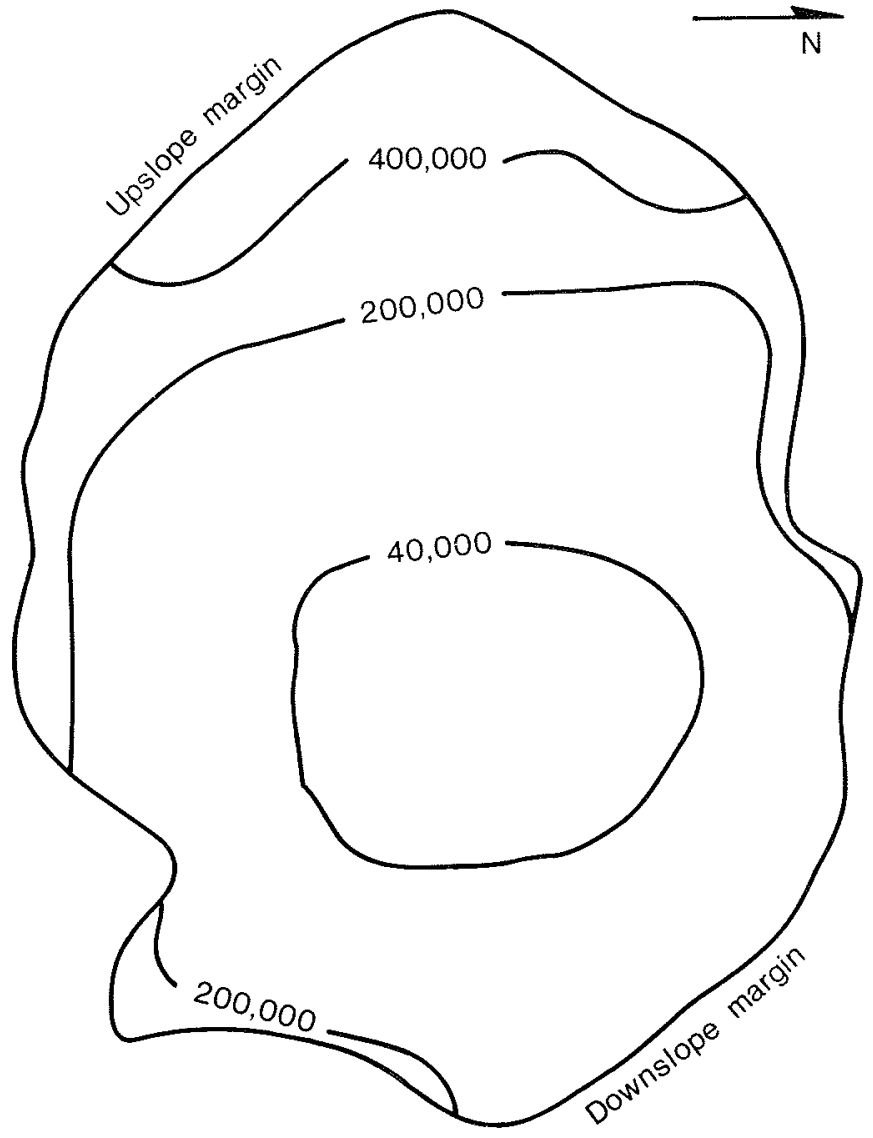

Scale: Chains

$\begin{array}{llllll}1 & & & 1 & 1 & 1\end{array}$

Figure 4.-The fall of sound seed on a 10-acre clearcut area during a bumper seed crop year (1964); seed fall was greatest on the upslope, windward margin (Jones 1967). trees. Lack of air mixing, however, could cause problems to trees at a distance from the edge. Small openings also enhance snow accumulations, as Plasencia (1988) found at Thomas Creek. Greater snowpacks, remaining on the site longer, should result in more soil moisture for tree growth and survival.

\section{Management Implications}

The implications of this study to management of mixed conifer forests are clear: patch clearcutting, or group-selection openings of similar sizes, will result in satisfactory regeneration of forest tree species. Although this fact was demonstrated for the 11-year period following harvesting at Thomas Creek, and for the range of openings studied, the findings also should be valid for similar old-growth stands, as well as for stands that had been lightly harvested in the past. Similar experiments should be conducted throughout the Southwest, in a variety of habitat types, and in openings of various sizes, to produce a more general conclusion. The Thomas Creek openings were regenerated with desirable conifer species and aspen. While regeneration was initially the same between the partially harvested forest and the clearings, relatively greater mortality eventually resulted in higher seedling densities in the forest. However, the differences may not be significant over the rotation, unless further drought produces more mortality in the clearings. Most larger seedlings should be able to survive future dry periods.

The results of the study can be evaluated in terms of the management recommendations for the Picea engelmannii/Senecio caradamine habitat type (USDA Forest Service 1986). The treatments produced satisfactory regeneration, and the species mixes expected from various silvicultural methods appear consistent with those for the habitat type. Clearcutting should favor aspen and Douglas-fir. Douglas-fir was favored in the Thomas Creek clearcuts but aspen was only important in a few areas. The factor missing in the habitat type recommendations is the size of clearcuts. Large clearings, such as at Willow Creek (Gottfried 1983), stimulated aspen reproduction, but small openings appeared to be less beneficial. This must be considered if aspen regeneration for wildlife is a prime objective. A knowledge of the relationship between species and optimum clearing sizes for successful regeneration would give managers more flexibility to manipulate stands to obtain the species composition specified in forest plans. The selection method should favor spruce; this species did increase throughout the study period, and by 1989 was the second most common species after white fir (fig. 2).

The Thomas Creek prescription is compatible with the integrated resource management philosophy, which recognizes that all natural resources are interrelated and that an interdisciplinary approach is necessary when designing projects (USDA Forest Service 1988). Satisfactory regeneration and increased growth of residual trees (Gottfried 1989) benefited the timber resource. These benefits coupled with the benefits of increased 
water yields (Gottfried 1989) and herbage production for cattle and wildlife (Ffolliott and Gottfried 1989) indicate the value of the experimental treatment at Thomas Creek. Forest managers should consider this type of prescription for multiresource management within the mixed conifer forests of the Southwest.

\section{Literature Cited}

Alexander, Robert R. 1974. Silviculture of central and southern Rocky Mountain forests: a summary of the status of our knowledge by timber types. Res. Pap. RM-120. Fort Collins, CO: U.S. Department of Agriculture, Forest Service, Rocky Mountain Forest and Range Experiment Station. 36 p.

Brown, Thomas C. 1976. Alternatives analysis for multiple use management: a case study. Res. Pap. RM-176. Fort Collins, CO: U.S. Department of Agriculture, Forest Service, Rocky Mountain Forest and Range Experiment Station. $16 \mathrm{p}$.

Embry, Robert S. 1971. Soil water availability in an Arizona mixed conifer clearcutting. Res. Note RM-206. Fort Collins, CO: U.S. Department of Agriculture, Forest Service, Rocky Mountain Forest and Range Experiment Station. $4 \mathrm{p}$.

Ffolliott, Peter F.; Gottfried, Gerald J. 1989. Production and utilization of herbaceous plants in small clearcuts in an Arizona mixed conifer forest. Res. Note RM-494. Fort Collins, CO: U.S. Department of Agriculture, Forest Service, Rocky Mountain Forest and Range Experiment Station. $5 \mathrm{p}$.

Fitzhugh, E. Lee; Moir, William H.; Ludwig, John A.; Ronco, Frank, Jr. 1987. Forest habitat types in the Apache, Gila, and part of the Cibola National Forests, Arizona and New Mexico. Gen. Tech. Rep. RM-145. Fort Collins, CO: U.S. Department of Agriculture, Forest Service, Rocky Mountain Forest and Range Experiment Station. $116 \mathrm{p}$.

Gottfried, Gerald J. 1983. Stand changes on a southwestern mixed conifer watershed after timber harvesting. Journal of Forestry. 81: 311-316.

Gottfried, Gerald J. 1987. Effects of modified skidding rules on mixed conifer advance regeneration in Arizona. Res. Note RM-479. Fort Collins, CO: U.S. Department of Agriculture, Forest Service, Rocky Mountain Forest and Range Experiment Station. 8 p.

Gottfried, Gerald J. 1989. Effects of patch clearcutting on water yield improvement and on timber production in an Arizona mixed conifer watershed. Tucson, AZ: University of Arizona, School of Renewable Natural Resources. 184 p. Ph.D. dissertation.

Hibbert, Aldon R. 1979. Vegetation management for water yield improvement in the Colorado River Basin.
National Technical Information Service No. PB300379/AS. $58 \mathrm{p}$.

Jones, John R. 1967. Regeneration of mixed conifer clearcuttings on the Apache National Forest. Res. Note RM-79. Fort Collins, CO: U.S. Department of Agriculture, Forest Service, Rocky Mountain Forest and Range Experiment Station. 8 p.

Jones, John R. 1971. Mixed conifer seedling growth in eastern Arizona. Res. Pap. RM-77. Fort Collins, CO: U.S. Department of Agriculture, Forest Service, Rocky Mountain Forest and Range Experiment Station. 19 p.

Jones, John R. 1972. Moisture stresses in Arizona mixed conifer seedlings. Res. Pap. RM-86. Fort Collins, CO: U.S. Department of Agriculture, Forest Service, Rocky Mountain Forest and Range Experiment Station. 8 p.

Jones, John R. 1974. Silviculture of southwestern mixed conifers and aspen: the status of our knowledge. Res. Pap. RM-122. Fort Collins, CO: U.S. Department of Agriculture, Forest Service, Rocky Mountain Forest and Range Experiment Station. 44 p.

Lee, Richard. 1978. Forest microclimatology. New York, NY: Columbia University Press. 276 p.

Plasencia, Douglas J. 1988. Effects of mixed conifer openings on snow. Tucson, AZ: University of Arizona. 30 p. M.S. thesis.

Rich, Lowell R.; Thompson, J. R. 1974. Watershed management in Arizona's mixed conifer forests: the status of our knowledge. Res. Pap. RM-130. Fort Collins, CO: U.S. Department of Agriculture, Forest Service, Rocky Mountain Forest and Range Experiment Station. $15 \mathrm{p}$.

Ronco, Frank, Jr.; Gottfried, Gerald J.; Alexander, Robert R. 1984. Silviculture of mixed conifer forests in the Southwest. Tech. Transfer Pap. RM-TT-6. Fort Collins, CO: U.S. Department of Agriculture, Forest Service, Rocky Mountain Forest and Range Experiment Station. $72 \mathrm{p}$.

Sexton, Bill. 1976. Soil resource inventory: Thomas Creek Research Watershed, Apache-Sitgreaves National Forests. Albuquerque, NM: U.S. Department of Agriculture, Forest Service, Southwestern Region, Region 3. $51 \mathrm{p}$.

U.S. Department of Agriculture, Forest Service. 1986. Forest and woodland habitat types of southern New Mexico and central Arizona. Albuquerque, NM: U.S. Department of Agriculture, Forest Service, Southwestern Region.

U.S. Department of Agriculture, Forest Service. 1988. Integrated resource management: project implementation process. Albuquerque, NM: U.S. Department of Agriculture, Forest Service, Southwestern Region. $36 \mathrm{p}$. 